\title{
Carbohydrate markers in colon carcinoma
}

\author{
Sławomir Dariusz Szajda ${ }^{\mathrm{a}}$, Anna Jankowska ${ }^{\mathrm{b}}$ and Krzysztof Zwierz ${ }^{\mathrm{a}, *}$ \\ ${ }^{a}$ Department of Pharmaceutical Biochemistry, Medical University of Bialystok, Bialystok, Poland \\ ${ }^{\mathrm{b}}$ Department of Pediatric Dentistry, Medical University of Bialystok, Bialystok, Poland
}

\begin{abstract}
Spontaneously mutated multiple oncogenes and/or tumor suppressor genes in colon epithelial cell and its progeny, may cause proliferation out of control and create benign colon neoplasm (colon polyp). If additional mutations involve genes responsible for cell adhesion and movement, aberrant epithelial cells may become malignant (colon cancer) and invade surrounding and remote tissues, creating secondary tumors called metastases.

Incidence of colorectal cancer dramatically increases at 50-65 year of age. In Europe in 2006 colorectal cancer consisted 12.9\% of all cancers and caused 207400 deaths.

To laboratory detection and monitoring of colon cancer are used tumor markers. Tumor markers are substances produced by the body in response to cancer, or by cancer tissue itself. Glycoconjugate markers for colon cancer include aberrant: mucins covering the surface of the colon epithelial cells, cadherins, selectins and Ig-like adhesion molecules mediating cell-cell adhesion, integrins and integral membrane proteoglycans responsible for adhesion of colon epithelial cells to extracellular matrix, glycoconjugate components of ECM, as well as lysosomal membrane glycoproteins and exoglycosidases.

Detection of colon cancer at early non malignant stage is crucial in its prevention and eradication. As colon cancer is the effect of accumulation many somatic mutations in oncogens, supressors, mismatch repair genes and many genes responsible for posttranslational modifications of proteins, multidirectional approach should be applied for its detection. A glycobiological approach to diagnosis and treatment of colorectal cancer should be directed to detection changes in glycosylation accompanying every step of colon cancer progression, and correlation between changes in glycosylation and tumor progression.
\end{abstract}

Keywords: Carbohydrate markers, colon carcinoma

\section{Introduction}

Normal regeneration of the mucosa of the gut, which is faster than in any other tissue, may cause proliferation of colon epithelial cells out of control and create benign colon neoplasm (colon polyp) through spontaneously mutated multiple oncogenes and/or tumor suppressor genes in colon epithelial cell, which are inheritable [2] (Fig. 1). If additional mutations involve genes coding proteins responsible for cell adhesion and movement, aberrant epithelial colon cells may become malignant (colon cancer), and invade surrounding and remote tissues, creating secondary tumors called metastases [2]. The evolution of colonic epithelial cells from normal to

* Corresponding author: Krzysztof Zwierz M.D., Ph.D., Professor, Department of Pharmaceutical Biochemistry, Medical University, Mickiewicza Str 2A, 15-230 Bialystok, Poland. Tel.: +48 85 7485690; Fax: +48 85 748416; E-mail: kzwie@umwb.edu.pl. malignant cells requires accumulation of spontaneous mutations in many genes which takes place over many decades, therefore colon cancer incidence dramatically grows between 50 and 70 years [24] (Fig. 2). About $20 \%$ of all patients with colon cancer have some inherited risk component without fulfilling the strict criteria for hereditary colorectal cancer [74]. Hereditary nonpolyposis colorectal cancer (HNPCC) and the different polyposis syndromes such as familial adenomatous polyposis (FAP) or Peutz-Jeghers disease are rare causes of colorectal cancer but have been a major focus of research in past years, helping with the understanding of the molecular events in carcinogenesis [54,67,74].

In Europe in 2006, the most common cancer was breast cancer (429 900 cases, $13.5 \%$ of all cancer cases), followed by colorectal cancers (412 900, 12.9\%) (Fig. 3), and lung cancer (386 300, 12.1\%). Lung cancer, with an estimated 334800 deaths (19.7\% of total), was the most common cause of death from can- 


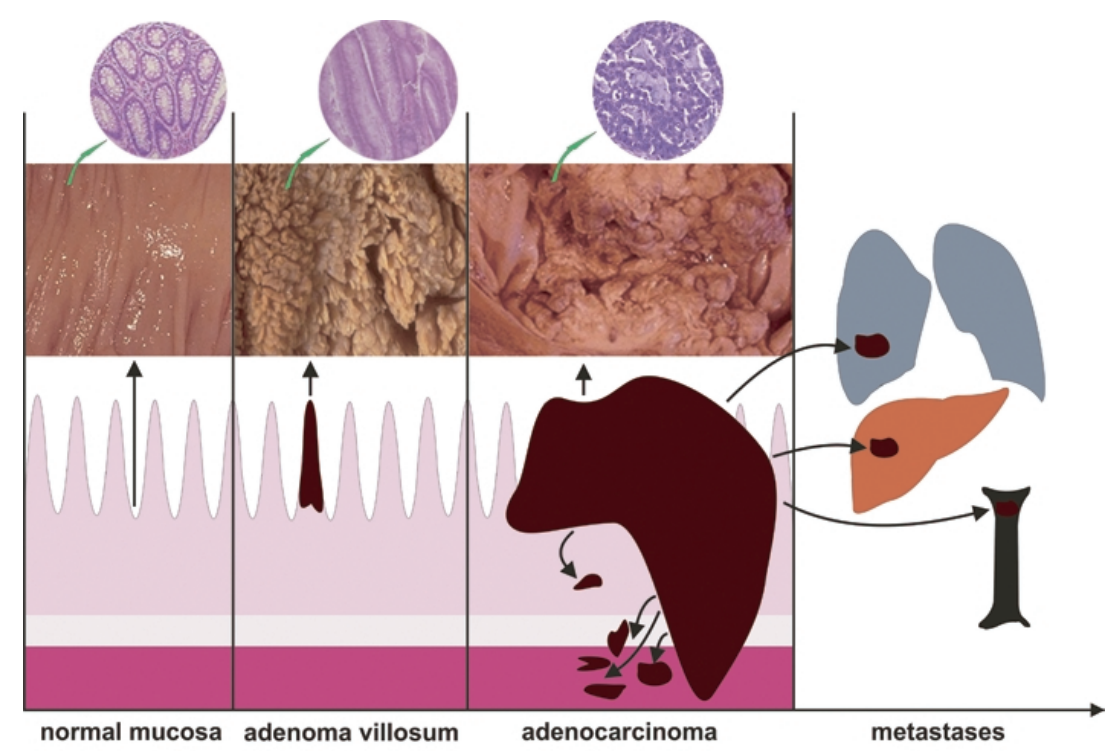

Fig. 1. Steps in colon cancer development.

cer, followed by colorectal (207 400 deaths), breast (131 900) and stomach (118 200) cancers [24]. The World Health Organization (WHO), estimates about a million new cases and about half a million of death due to colorectal cancer per year [74]. Colorectal cancer is more widespread in developed, than in developing countries, however better health care results in higher survival rate in developed ( $60 \%$ for 5 year in USA), and less than $40 \%$ in less developed countries (30.8-32.4\% for 5 year in Poland) [74].

A tumor marker is defined as a substance produced by the body in response to cancer or by the cancer tissue itself [61]. Therefore a tumor marker candidate may by any component of the body changed qualitatively or quantitatively by the neoplastic process to be sufficiently distinct from its normal counterpart. Glycoconjugate candidates for colon cancer markers include aberrant: mucins covering the surface of the colon epithelial cells, cadherins, selectins and Ig-like cell adhesion molecules mediating cell-cell adhesion, integrins and integral membrane proteoglycans responsible for the adhesion of colon epithelial cells to extracellular matrix, glycoconjugate components of colon extracellular matrix, and lysosomal membranes glycoproteins and exoglycosidases [12].

\section{Abnormal colonic mucins}

Mucins, are high- molecular weight epithelial glycoproteins with a high content of clustered oligosac-

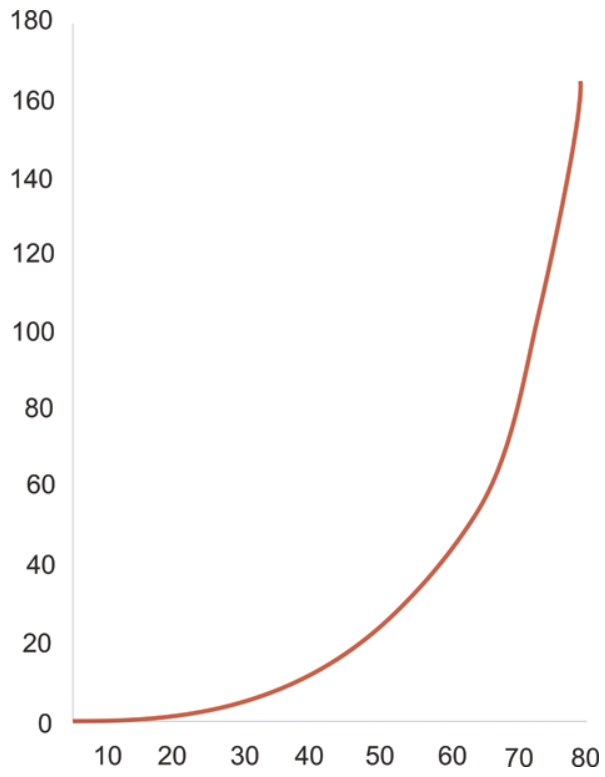

Fig. 2. Cancer incidence as a function of age. The diagram is based on the data published by Muir and Waterhouse [51]. [C2002 from Molecular Biology of the Cell, $4 \mathrm{E}$ by Alberts et al. Reproduced by permission of Garland Science/Taylor \& Francis, LLC.]

charides O- glycosidally linked to tandem repeat peptides rich in threonine, serine and proline. Mucins characteristically have a large number of relatively short oligosaccharides containing $\mathrm{N}$-acetyl galactosamine linked O- glycosidically [78]. 18 genes encoding mucins have been described to date: secreted (MUC: 1; 5AC; 5B; 6), transmembrane (MUC: 1; 3A; 


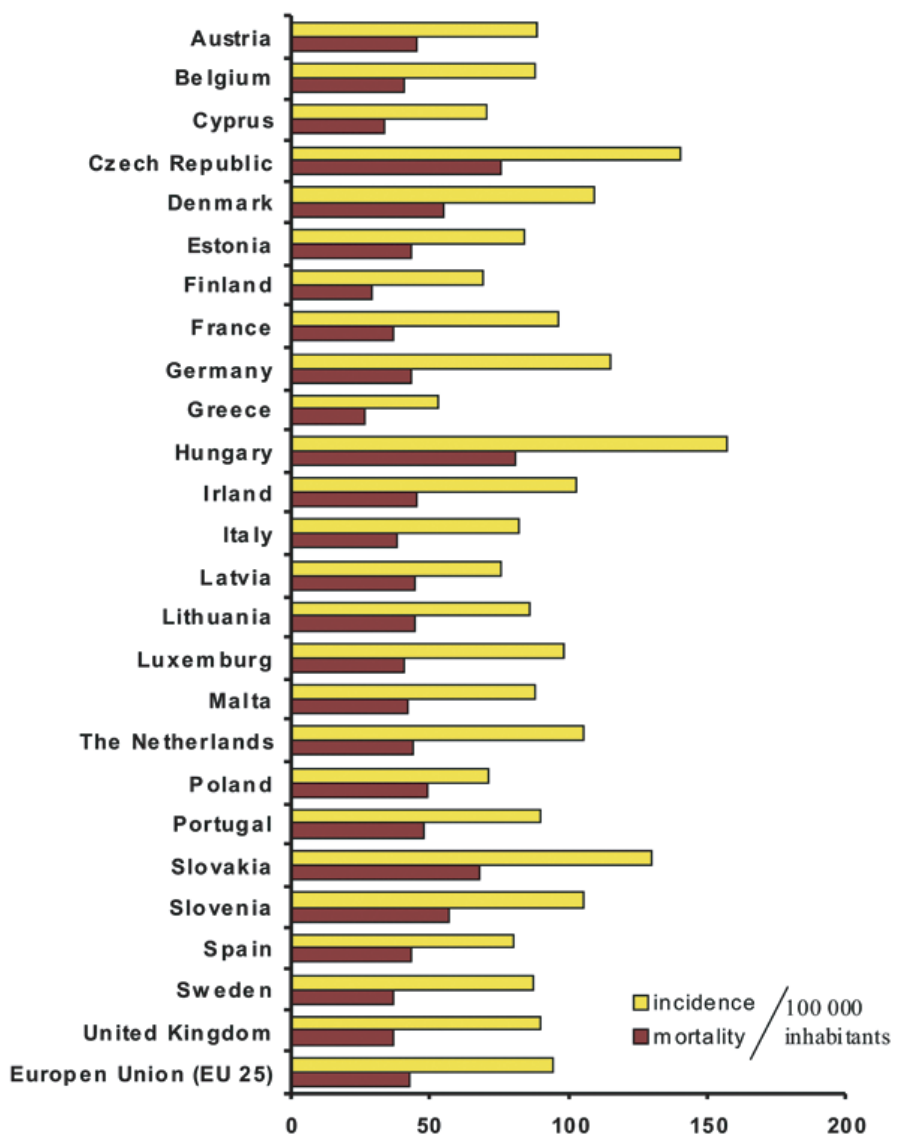

Fig. 3. Colon and rectum cancer estimated age-standardised incidence and mortality rates (European standard) per 100000 [International Classification of Diseases (ICD)-C18-21]

$3 \mathrm{~B} ; 4 ; 12 ; 17)$ and some not fitting in to the above class (MUC: $7 ; 8 ; 9 ; 13,15 ; 16)$. In cancerous and precancerous stages of colon cancer changes have been reported in the protein as well as in the core, backbone and peripheral structures of oligosaccharide chains of colonic mucins [12].

\section{Cancer related changes in protein chains of colonic mucins}

The expression of the MUC1 gene encoding a transmembrane mucin in colon cancers (mostly at metastatic stages) is increased as compared to its expression in normal colon [53]. Moreover, in normal colon there is no, or little reaction with monoclonal antibodies directed against the protein part of MUC1, although MUC1 mRNA is detectable in normal colon. The protein part of MUC1 must therefore be masked in normal colon. Partial removal of carbohydrates, was found to unmask the protein core in both goblet cells and columnar ep- ithelial cells of the colon. In colorectal adenocarcinomas and adenomatous polyps, MUC1 is less glycosylated than in normal cells, allowing its immunodetecion [12].

Expression of MUC1 protein may be a marker of poor prognosis in cancer [53] and metastases to the liver [49].

In colorectal carcinomas, the number of cells positively stained for MUC1 is higher than that of MUC2. In carcinomas containing an adenomatous component, cells positively stained for MUC1 were not observed in adenomatous, but observed in carcinomatous areas. In contrast, the number of cells positively stained for MUC2 was higher in adenomatous than in carcinomatous areas [49]. Matsuda et al. claimed that up- regulation of MUC1 and down- regulation of MUC2 are involved in tumor progression through the adenomacarcinoma sequence. They also observed that MUC1 expression seems to be related to tumor progression to advanced stages, which may suggest that MUC1 upregulation may be involved in the progression of carci- 
noma from non- metastatic to the metastatic stage. Matsuda et all concluded that MUC1 could be a marker for synchronous metastasis in colorectal carcinomas [49].

A decrease of $M U C 2$ apomucin expression in colon adenocarcinoma has been reported [5,57], but not in mucinous colon carcinomas [49]. The clinical significance of MUC1, MUC2 and p53 protein expression, in colorectal carcinoma has been demonstrated [49]. Experiments on animals suggested that decreased expression of MUC2 may contribute to colonic carcinogenesis [77], by increased proliferation and migration but decreased apoptosis of colon epithelial cells. In the case of adenomas, expression of apomucins is associated with polyp size, villosity and the degree of dysplasia. Investigation of mucin expression in colorectal tubular adenomas revealed an increase of MUC1 in foci with high-grade atypia and extension through the crypt length with increasing atypia [1].

MUC5AC is not expressed in normal colon, but is expressed in colon adenomas and carcinomas [13]. MUC5AC apomucin can be suggested as a marker of well and moderately differentiated colon neoplasms [4], but not in a poorly differentiated colon cancers [5], as well as a marker of worse prognosis than MUC5AC positive cases [43]. Aberrant MUC5AC gene expression cannot be used to predict local recurrence of villous and tubulovillous adenomas [47].

It was reported that MUC11/MUC12, were downregulated in colon cancer [76].

\section{Cancer related changes in oligosaccharide chains of colonic mucins}

In comparison to normal colonic mucins [17], cancerous human colonic mucins are based on core 1, 2 and 4 but not core 3 (Fig. 4A), have reduced oligosaccharide length, and total carbohydrate content $[6,16]$. The premalignant mucins of colon polyps detected in tissue and serum, are Tn (GalNAc $\alpha 1$-Ser/Thr) and TF antigen (Gal $\beta 1-3 \mathrm{GalNAc} \alpha 1-\mathrm{Ser} / \mathrm{Thr}$ ) [79]. T, Tn and sialosyl-Tn antigens (Figure 4B) are colon cancer associated antigens. Tn and sialosyl $-\mathrm{Tn}$ may be useful markers of poorly differentiated adenocarcinomas and mucinous carcinomas [41]. Tn and TF antigens were found to be sialylated in majority of cancer metastatic colon cells [65]. Colon cancer tissues were shown to present an increased content of $\alpha 2,6$ sialyl- $\beta$ galactosides [20], and increased CMP-NeuAc:Gal $\beta 1$ 4GlcNAc:2,6-sialyltransferase activity have been described in tumor and serum [27]. Sialyl-Tn antigen in stools may be a marker of: noninvasive colorectal cancer screening [62], colon cancer metastasis [9], associated with poor prognosis [38] and increased risk of cancer in ulcerative colitis [40,62]. Colonic cancer mucins were reported to have lost sulfate groups linked to galactose [12], and O-acetate groups of sialic acids [19].

In peripheral structures of oligosaccharide chains of human colonic mucins the reappearance of $\mathrm{ABH}$ groups was described (distal lesions) or $\mathrm{ABH}$ deletion (proximal lesions) and occasionaly expression incompatible A or B substances [39], and there is decreased expression of some blood group antigens in colon cancer, in comparison to control. However in colon cancer there is an increase in sialylated Lewis ${ }^{\mathrm{a}}$ and Lewis $\mathrm{X}$ [46]. Sialyl LeX on the peripheral carbohydrates of MUC1 and 2 as well as glycoproteins of CEA family, and lysosomal membrane glycoproteins, have been reported to be a marker of increase in metastasis [59], associated with poor prognosis [38] and decreased survival of colon carcinoma patients [9]. Decreased survival of colon carcinoma patients are probably caused by binding sialyl LeX to E- selectins [28]. A mucin containing sialylated Lewis epitope, known as CA 19-9 is a widely investigated colon carcinoma marker, providing little independent prognostic extra information to that of CEA [23], however it is yet not recommended for early diagnosis and monitoring of colon cancer [22].

Galectin 1 is a lectin responsible for $\beta$-galactoside, lactose and $\mathrm{N}$-acetyllactosamine binding, which can mediate or inhibit tumor cell adhesion to ECM [15]. Galectin 1 expression is increased in stroma and epithelial colon cancer [32]. Galectin 1 may be a colon cancer prognostic marker [52]. Another marker of colorectal cancer may be increased serum concentration of galectin-3, which particularly increases in metastatic stage of disease [37].

\section{Cancer related changes in colonic $\mathrm{N}$-glycans}

Highly metastatic human colon carcinomas express more poly-N-acetyllactosaminyl side chains in $\mathrm{N}$ glycans of lysosomal membrane glycoproteins (expressed at the cell surface), which are more sialylated but less fucosylated, and correlate with the increased expression of sialyl $\mathrm{Le}^{\mathrm{x}}$ structures, than cells with low metastatic potential [66]. 


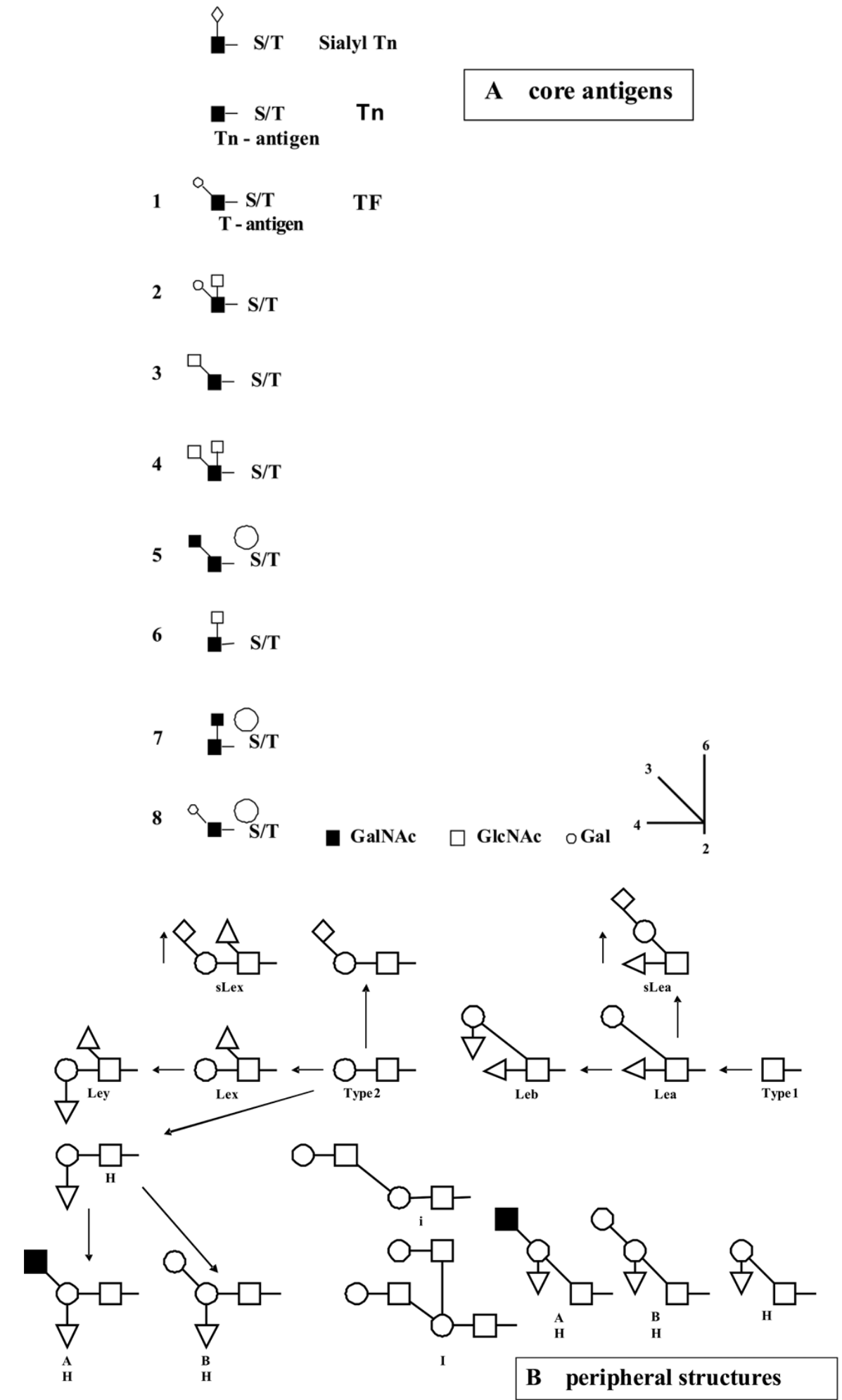

Fig. 4. Antigenic determinants of oligosaccharide chains: core antigens (A), peripheral structures (B). The diagram is based on the data published by Zalewska et al. [78]. [Reproduced with permission from A. Zalewska et al.: Acta Biochim Pol 47 (2000), 1067-1079]. 


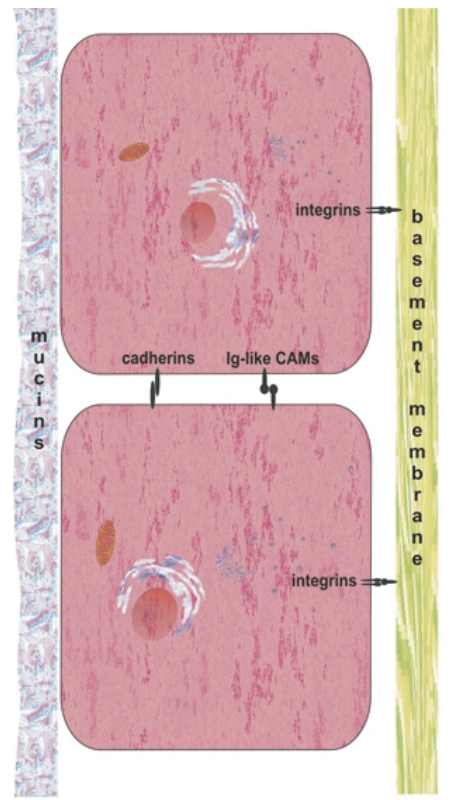

normal cell

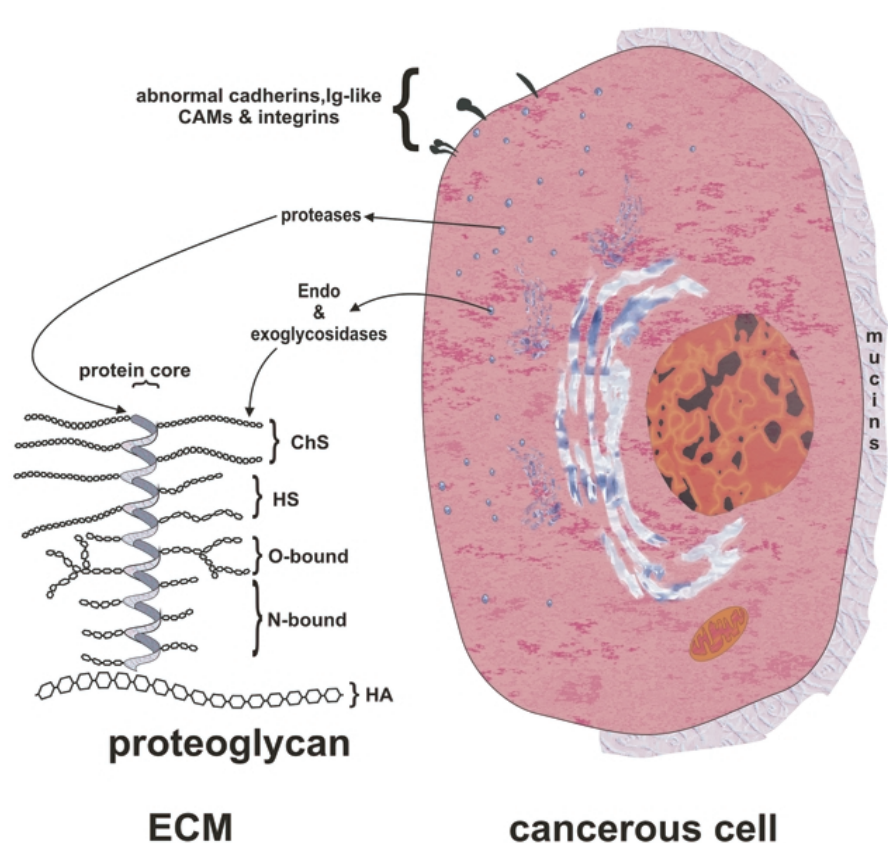

cancerous cell

Fig. 5. Adhesion molecules in colon cancer.

\section{E-Cadherin-mediated cell adhesion in colorectal cancer}

E-cadherin is homophilic epithelial cell-cell adhesion integral membrane glycoprotein (Fig. 5) with a single transmembrane domain, and cytoplasmic tail connected by $\alpha$ and $\beta$ catenins with actin filaments [31]. Detachment of cells from the primary tumor mass is possible when E-cadherins are inactivated [73]. It was reported that aberrant phosphorylation of $\beta$-catenin is responsible for invasion, and metastasis [69] of colon cancer cells to liver [36].

\section{Integrin-mediated cell adhesion in colorectal cancer}

Integrins are cell-extracellular matrix adhesion heterodimeric transmembrane glycoproteins, which are composed of one of 24 types of $\alpha$ - and one of 9 types of $\beta$-subunits [2,35]. Reduced expression of the $\alpha_{2}$ subunit was significantly associated with malignancy and lymph node metastasis of colorectal cancer [44]. Decreased glycosylation of integrins, decreases adhesiveness of colorectal cancer cells, to the extracellular matrix [45]. In colorectal cancer altered (increased or decreased) expression in integrin $\beta_{1}$-subunit, correlate positively with invasion, lymph node metastasis, and depth of invasion [25].

\section{Cell adhesion molecules in colorectal cancer}

Carcinoembryonic antigen (CEA) is cell adhesion, highly $\mathrm{N}$-glycosylated (28 potential sites of $\mathrm{N}$ glycosylation), glycoprotein of immunoglobulin superfamily [58], linked to the apical colon endothelial cell membrane by phosphatidylinositol link [23]. It was suggested that decrease in the molecular weight of human colonic CEA could be related to the degree of transformation and decrease in glycosylation [26]. CEA is not suitable for screening for early colorectal cancer, because of low sensitivity in early stages and elevation without malignancy [21], but is recommended that it is measured every 2-3 months [23], for evaluate prognosis, and surveillance following curative resection and monitoring therapy in advanced disease [22].

\section{Extracellular matrix glycoproteins in colorectal cancer}

TIMP-1 (Tissue inhibitor of metalloproteinase type 1) is a multifunctional glycoprotein with metalloproteinase activity, which stimulates cell growth and inhibits apoptosis [18]. Increased plasma levels of TIMP were found in colorectal cancer [33], and high preoperative plasma levels of TIMP-1 predicted unsuccessful outcome in patients with colorectal cancer [34], how- 
ever the European group of tumor markers yet does not recommend TIMP-1 determination for screening as well as monitoring of colon cancer [22].

\section{Immune complexes in colorectal cancer}

TA90-IC is a $90 \mathrm{kDa}$ glycoprotein, which circulates in the serum bound to IgG. TA90 is expressed in colon cancer and was proposed as a new marker for advanced colon cancer [30].

\section{Lysosomal exoglycosidases in colorectal cancer}

Leucocytes (macrophages, neutrophils, eosinophils, dendrocytes, mast cells and lymphocytes) which infiltrate colon cancer tissue are associated with the absence of pathological evidence of early metastases and prolonged survival [60]. Macrophages, and mast cells as well as neutrophils take part in progression, and transformation of colon cancer cells [75]. Macrophages degrade "foreign" cells, secrete proteases, exoglycosidases, and cytokines promoting tumor progression and metastasis [64]. Activities of lysosomal exoglycosidases including $\beta$-galactosidase, $\alpha$-mannosidase and neuraminidase which take part in degradation and remodeling of colon tissues [7], as well as $\beta$-hexosaminidase activity $[29,63]$ are significantly increased in colon cancer tissue, in comparison to activities in normal colon. Human colonic carcinoma tissue contained a higher proportion of $\beta$-hexosaminidase $\mathrm{B}$ (termostable) than hexosaminidase A (termolabile), while normal human colonic mucosa contained higher proportion of $\beta$-hexosaminidase $\mathrm{A}$ than $\mathrm{B}$ [8]. In one human colonic carcinoma cell line it was found termolabile $\beta$-hexosaminidase B [42]. In neutrophils of peripheral blood of patients with digestive tract cancer there was observed decrease in $\beta$-glucuronidase and increased $\beta$-hexosaminidase activity [70]. It was reported that activity and properties of $\alpha$-L-fucosidase are dependent on the state of enterocytic differentiation of HT-29 colon cancer cells [50]. The activity of $\alpha$-L-fucosidase in sera of patients with colorectal cancers was higher in patients with distant metastases than in lymph node, peritoneal metastases or without metastasis, which suggested the use of serum $\alpha$-L-fucosidase activity as a prognostic marker in colorectal cancer [3] associated with the type of metastasis. In colorectal cancer it was reported increase in activity of lysosomal exoglycosidases in serum [71,72] and urine [72].

\section{Markers in noninvasive screening of colorectal cancer}

When colon epithelial cells are clustered together, colon tumor (usually polyp) is easy to complete eradication by simple colonoscopical or surgical procedures. However, eradication of colon cancer metastases is costly and extremely difficult [75].

Reported data following a 5 year survival rates at primary diagnosis are for: localized disease (Duke's stage A and B) 82-93\%, regional disease (stage C) 55-60\% and $8 \%$ for metastatic disease (stage D), respectively [56]. Therefore detection of colon cancer at early non malignant stage is crucial in prevention of colorectal cancer, which was appreciated by Senat and president of USA who declared March 2000 as Colorectal Cancer Awareness Month [68]. For population screening: faecal occult blood test (FOBT), or faecal immunochemical test (FIT), double contrast Barium enema, sigmoidoscopy, combination of FOBT and sigmoidoscopy and colonoscopy are recommended [11]. Biennial screening by fecal occult blood test and endoscopy resulted in 15-20\%, and annual screening resulted in a $33 \%$ reduction o colon cancer mortality [48]. Colonoscopy and sigmoidoscopy are expensive, invasive, carries a risk of serious complications [55] and are unpleasent for patients. In the 2007 guidelines for clinical use of tumor markers in colorectal cancer European Group of Tumor Markers (EGTM) [22], there are no proposals for glycoconjugates, as a markers for colon cancer screening.

\section{Conclusions and future developments}

As a colon cancer is the effect of accumulation many somatic mutations in oncogenes, supressor and mismatch repair genes [14] as well as other genes responsible for posttranslational modifications of proteins [10] multidirectional approach should be applied for its detection. Among others (e.g. FOBT, double contrast Barium enema, sigmoidoscopy, colonoscopy) [11], in screening and early diagnosis, monitoring, prognosis and predicting response to therapy [23] carbohydrate based markers of colorectal cancer should be used. Real challenge is application glycoconjugate markers for screening for colorectal cancer. Such candidate may be STn epitope [62], however the possibility of determination in faeces an aberrant colonic mucins and their oligosaccharide chains should be tested. For monitoring, prognosis and predicting response to therapy some 
glycoconjugate based serum markers (such as CEA) are already recommended, and others (as Ca19.9 and TIMP) are under evaluation [22]. A glycobiological approach to diagnosis and treatment of colorectal cancers should be directed to detection changes in glycosylation accompanying every step of cancer progression, and correlation between changes in glycosylation with tumor progression. Models of experimental colon carcinogenesis should be established for examination of changes in glycosylation in different stages of carcinogenesis. Existing panels of carbohydrate based markers of colon cancer should be expanded to enhance their sensitivity and specificity, and modified to cut costs (e.g. by automation of existing procedures). Glycobiologists should work in multidisciplinary expert panels working for large international organizations (e.g European Union or WHO), who are able to coordinate cooperation with clinicians (e.g. in preparation of patients for screening), governmental agencies (which provide necessary resources) and media which are very important in raising public awareness and public utilization of screening.

\section{Acknowledgments}

We are greatly indebted to Dr. Tony Merry of Glycoscience Consultancy, Oxford, U. K for his critical reading of the manuscript.

\section{References}

[1] Y. Ajioka, L.J. Allison and J.R. Jass, Significance of MUC1 and MUC2 mucin expression in colorectal cancer, $J$ Clin Pathol 49 (1996), 560-564.

[2] B. Alberts, A. Johnson, J. Lewis, M. Raff, K. Roberts and P. Walter, Molecular Biology of the Cell, 4th ed., Garland Science, N.Y., 2002, pp. 1313-1362

[3] D. Ayude, M.P. de la Cadena, V.S. Martinez-Zorzano, A. Fernandez-Briera and F.J. Rodrigeuez-Berrocal, Preoperative serum alpha-L-fucosidase activity as a prognostic marker in colorectal cancer, Oncology 64 (2003), 36-45.

[4] A.E. Bartman, S.J. Serson, S.L. Ewing, G.A. Niehans, C.L. Wiehr, M.K. Ewans and S.B. Ho, Aberrant expression of MUC5AC and MUC6 gastric mucin genes in colorectal polyps, Int J Cancer 80 (1999), 210-218.

[5] A.E. Biemer-Huttmann, M.D. Walsh, M.A. McGuckin, L.A. Simms, J. Young, B.A. Leggett and J.R. Jass, Mucin core protein expression in colorectal cancers with high levels of microsatelite instability indicates a novel pathway of morphogenesis, Clin Cancer Res 6 (2000), 1909-1916.

[6] C.R. Boland and G.D. Deshmukh, The carbohydrate composition of mucin in colonic cancer, Gastroenterol 98 (1990), 1170-1177.
[7] B.H. Bosmann and T.C. Hall, Enzyme activity in invasive tumors of human breast and colon, Proc Nat Acad Sci USA 71 (1974), 1833-1837.

[8] M.G. Brattain, P.M. Kimball and T.G. Pretlow, $\beta$ hexosaminidase isoenzymes in human colonic carcinoma, Cancer Res 37 (1977), 731-735.

[9] R.S. Bresalier, S.B. Ho, H.L. Schoeppner, Y.S. Kim, M.H. Sleisenger, O. Brodt and J.C. Byrd, Enhanced sialylation of mucin-associated carbohydrate structures in human colon cancer metastasis, Gastroenterol 110 (1996), 1354-1367.

[10] I. Brockhausen, Pathways of O-glycan biosynthesis in cancer cells, Bioch Biophys Acta 1473 (1999), 67-95.

[11] R.W. Burt, Colon cancer screening, Gastroenterol 119 (2000), $837-853$.

[12] J.C. Byrd and R.S. Bresalier, Mucins and mucin binding proteins in colorectal cancer, Cancer Metast Rev 23 (2004), 7799.

[13] J.C. Byrd, L. Sternberg, P. Yan, S.B. Ho and R.S. Bresalier, Ectopic expression of MUC5 gastric mucin in colorectal adenocarcinoma, Gastroenterol 114 (1998), A573.

[14] P.M. Calvert and H. Frucht, The genetics of colorectal cancer, Ann Int Med 137 (2002), 603-612.

[15] I. Camby, M. Le Mercier, F. Lefranc and R. Kiss, Galectin-1: a small protein with major function, Glycobiology 16 (2006), 137R-157R.

[16] C. Capon, C.L. Laboisse, J.M. Wieruszeski, J.J. Maoret, C. Augeron and B. Fournet, Oligosaccharide structures of mucins secreted by the human colonic cancer cell line CL.16E, J Biol Chem 267 (1992), 19248-19257.

[17] C. Capon, E. Maes, J.C. Michalski, H. Leffler and Y.S. Kim, Sda-antigen-like structures carried on core 3 are prominent features of glycans from the mucin of normal human descending colon, Biochem J 358 (2001), 657-664.

[18] A.F. Chambers and L. Matrisian, Changing views of the role of matrix metalloproteinases in metastasis, J Natl Cancer Inst 89 (1997), 1260-1270.

[19] A.P. Corfield, N. Myerscough, B.F. Warren, P. Durdey, C. Paraskeva and R. Schauer, Reduction of sialic acid $\mathrm{O}$-acetylation in human colonic mucins in the adenomacarcinoma sequence, Glycoconj J 16 (1999), 307-317.

[20] F. Dall'Olio, M. Chiricolo, C. Cecarelli, F. Minni, D. Marrano and D. Santini, $\beta$-galactoside $\alpha 2,6$ sialyltransferase in human colon cancer: contribution of multiple transcripts to regulation of enzyme activity and reactivity with Sambucus nigra agglutin, Int J Cancer 88 (2000), 58-65.

[21] M.J. Duffy, CEA as a marker for colorectal cancer: is it clinically useful, Clin Chem 47 (2001), 624-630.

[22] M.J. Duffy, A. van Dalen, C. Haglund, L. Hansson, E. Holinski-Feder, R. Klapdor, R. Lamerz, P. Peltomaki Lloyd, C. Sturgeon and O. Topolcan, Tumour markers in colorectal cancer: European group on tumour markers (EGTM) guidelines for clinical use, Eur J Cancer 43 (2007), 1348-1360.

[23] M.J. Duffy, A. van Dahlen, C. Haglund, L. Hansson, R. Klapdor, R. Lamerz, O. Nilsson, C. Sturgeon and O. Topolcan, Clinical utility of biochemical markers in colorectal cancer: European group on tumor markers (EGTM) guidelines, Eur $J$ Cancer 39 (2003), 718-727.

[24] J. Ferlay, P. Gautier, M. Boniol, M. Heanue, M. Colombet and P. Boyle, Estimates of the cancer incidence and mortality in Europe in 2006, Ann Oncol 18 (2007), 581-592.

[25] S. Fujita, M. Watanabe, T. Kubota, T. Teramoto and M. Kitajima, Alterations of expression in integrin $\beta_{1}$-subunit correlate with invasion and metastasis in colorectal cancer, Cancer Lett 91 (1995), 145-149. 
[26] M. Garcia, C. Seigner, C. Bastid, R. Choux, M.J. Payan and H. Reggio, Carcinoembryonic antigen has a different molecular weight in normal colon and in cancer cells due to $\mathrm{N}$ glycosylation differences, Cancer Res 51 (1991), 5679-5686.

[27] P. Geßner, S. Riedl, A. Quentmaier and W. Kemmner, Enhanced activity of CMP-NeuAc: Gal $\beta 1-4 G l c N A c: 2,6-$ sialyltransferase in metastasizing human colorectal tumor tissue and serum of tumor patients, Cancer Lett 75 (1993), 143149.

[28] R. Giavazzi, M. Foppolo, R. Dossi and A. Remuzzi, Roling and adhesion of human tumor cells on vascular endothelium under physiological flow conditions, J Clin Invest 92 (1993), 3038-3044.

[29] E. Gil-Martin, J. Rodriguez-Berrocal, M. Paez de la Cadena and A. Fernandez-Briera, Alterations of glycosidases in human colonic adenocarcinoma, Clin Biochem 30 (1997), 1725.

[30] N. Habal, R.K. Gupta, A.J. Bilchik, T. Johnson and D.L. Morton, TA90-IC, a new marker for advanced colon cancer, Ann Surg Oncol 7 (2000), 352-356.

[31] S. Hirohashi, Inactivation of the E-cadherin-mediated cell adhesion system in human cancers, Am J Pathol 153 (1998), 333-339.

[32] A. Hittelet, H. Legendre, N. Nagy, Y. Bronckart, J.C. Pector, I. Salmon, P. Yeaton, H.J. Gabius, R. Kiss and I. Camby, Upregulation of galectins- 1 and 3 in human colon cancer and their role in regulating cell migration, Int J Cancer 103 (2003), 370-379.

[33] M.N. Holten-Andersen, I.J. Christensen, H.J. Nielsen, R.W. Stephens, V. Jensen, O.H. Nielsen, S. Sørensen, J. Overgaard, H. Lilja, A. Harris, G. Murphy and N. Brünner, Total levels of tissue inhibitor of metalloproteinase 1 in plasma yield high diagnostic sensitivity and specificity in patients with colorectal cancer, Clin Cancer Res 8 (2002), 156-164.

[34] M.N. Holten-Andresen, R.W. Stephens, H.J. Nielsen, G. Murphy, I.J. Christensen, W. Stetler-Stevenson and N. Brünner, High preoperative plasma tissue inhibitor of metalloproteinase 1 are associated with short survival of patients with colorectal cancer, Clin Cancer Res 6 (2000), 4292-4299.

[35] R.O. Hynes, Integrins: versality, modulation, signaling in cell adhesion, Cell 69 (1992), 11-25.

[36] F. Inomata, A. Ochiai, K. Sugihara, Y. Moria, N. Yamahuchi, Y. Adach, S. Kitano and S. Hirohashi, Macroscopic features at the deepest site of tumor penetration predicting liver metastases of colorectal cancer, Jpn Clin Oncol 28 (1998), 123-128.

[37] H. Inufusa, M. Nakamura, T. Adachi, M. Aga, M. Kurimoto, Y. Nakatani, T. Wakano, M. Miyake, K. Okuno, H. Shiozaki and M. Yasutomi, Role of galectin -3 in adenocarcinoma liver metastasis, Int J Oncol 19 (2001), 913-919.

[38] S.H. Itzkowitz, E.J. Bloom, W.A. Kokal, G. Modin, S. Hakomori and Y.S. Kim, Sialosyl Tn, a novel mucin antigen associated with prognosis in colorectal cancer patients, Cancer $\mathbf{6 6}$ (1990), 1960-1966.

[39] S.H. Itzkowitz, R. Dahiya, J.C. Byrd and Y.S. Kim, Blood group antigen synthesis and degradation in normal and cancerous colonic tissues, Gastroenterol 99 (1990), 431-442.

[40] S.H. Itzkowitz, E. Young, D. Dubois, N. Harpaz, C. Bodian, A. Chen and D.B. Sachar, Sialosyl-Tn is prevalent and precedes dysplasia in ulcerative colitis: A retrospective case-control study, Gastroenterol 110 (1996), 694-704.

[41] S.H. Itzkowitz, M. Yuan, C.K. Mongomery, T. Kjeldsen, H.K. Tskahashi, W.L. Bigbee and Y.S. Kim, Expression of Tn, sialosyl-Tn, and $\mathrm{T}$ antigens in human colon cancer, Cancer Res 49 (1989), 197-204.
[42] P.M. Kimball, M.G. Brattain and W.E. White, Characterization of an unusual isoenzyme of $\mathrm{N}$-acetyl- $\beta$-D-hexosaminidase from a human colonic carcinoma cell line, Biochem $J 193$ (1981), 109-113.

[43] B. Kocer, A. Soran, S. Erdogan, M. Karabeyoglu, O. Yildirim, A. Eroglu, B. Bozkurt and O. Cengiz, Expression of MUC5AC in colorectal carcinoma and relationship with prognosis, Pathol Int 52 (2002), 470-477.

[44] K. Koretz, P. Schlag, L. Boumsell and P. Moller, Expression of VLA- $\alpha_{2}$, VLA- $\alpha_{6}$, VLA- $\beta_{1}$ chains in normal mucosa and adenomas of the colon, and in colon carcinomas and their liver metastasis, Am J Pathol 138 (1991), 741-750.

[45] B.V. Lampe, A. Stallmach and E.O. Riecken, Altered glycosylation of integrin adhesion molecules of the human fibronectin receptor, J Biol Chem 264 (1993), 18011-18018.

[46] K.O. Lloyd, The chemistry and immunochemistry of blood group A, B, H and Lewis antigens: Past, present and future, Glycoconj 17 (2000), 531-541.

[47] R.J. Longman, J. Douthwaite, P.A. Sylvester, D. O'Leary, B.F. Waren, A.P. Corfield and M.G. Thomas, Lack of mucin MUC5AC field change expression associated with tubulovillous and villous colorectal adenomas, J Clin Pathol 53 (2000), 100-104.

[48] J.S. Mandel, J.H. Bond, T.R. Church, D.C. Snover, G.M. Bradley, L.M. Schuman and F. Ederer, Reducing mortality from colorectal cancer by screening for fecal occult blood. Minnesota Colon Cancer Control Study, $N$ Engl J Med 328 (1993), 1365-1371.

[49] K. Matsuda, T. Masaki, T. Watanabe, J. Kitayama, H. Nagawa, T. Muto and Y. Ajioka, Clinical significance of MUC1 and MUC2 and p53 protein expression in colorectal carcinoma, Jpn J Clin Oncol 30 (2000), 89-94.

[50] A. Merino-Trigo, F.J. Rodriguez-Berrocal, E. de Miguel and M.P. de la Cadena, Activity and properties of $\alpha$-L-fucosidase are dependent on the state of enterocytic differentiation of HT-29 colon cancer cells, Int J Biochem Cell Biol 34 (2002), 1291-1303.

[51] C. Muir and J. Waterhouse, Comparability and quality of data: Reliability of registration, in: Cancer Incidence in Five Continents, Volume V, C. Muir, J. Waterhouse, T. Mack et al., eds, IARC scientific publication No. 88, Lyon, France, International Agency for Research on Cancer, 1987, pp. 45-169

[52] N. Nagy, H. Legendre, O. Engels, S. Andre, H. Kaltner, K. Wasano, Y. Zick, J.C. Pector, C. Decaestecker, H.J. Gabius, I. Salmon and R. Kiss, Refined prognostic evaluation in colon carcinoma using immunohistochemical galectin fingerprinting, Cancer 97 (2003), 1849-1858.

[53] S. Nakomori, D.M. Ota, K.R. Cleary, K. Shirotani and T. Irimura, MUC1 mucin expression as a marker of progression and metastasis of human colorectal cancer, Gastroenterol 106 (1994), 353-361.

[54] NCCN Clinical Practice Guidelines in Oncology: Colorectal Cancer Screening 1v, 2006.

[55] F.B. Nicholson, J.L. Barro, W. Atkin, R. Lilford, J. Patnick, C.B. Williams, M. Pignone, R. Steele and M.A. Kamm, Review article: population screening for colorectal cancer, Aliment Pharmacol Ther 22 (2005), 1069-1077.

[56] J.B. O'Connel, M.A. Maggard and C.Y. Ko, Colon cancer survival rates with the staging American Joint Committee on cancer, sixth edition, J Natl Cancer Inst 96 (2004), 1420-1425.

[57] S. Ogata, H. Uehara, A. Chen and S.H. Itzkowitz, Mucin gene expression in colonic tissues and cell lines, Cancer Res 52 (1992), 5971-5978. 
[58] S. Oikawa, H. Nakazato and G. Kosaki, Primary structure of human carcinoembryonic antigen (CEA) deduced from cDNA sequence, Biochem Biophys Res Communs 142 (1987), 511518.

[59] M. Ono, M. Sakamoto, Y. Ino, Y. Moriya, K. Sugihara, T. Muto and S. Hirohashi, Cancer cell morphology at the invasive front and expression of cell adhesion-related carbohydrate in the primary lesion of patients with colorectal carcinoma with liver metastasis, Cancer 78 (1996), 1179-1186.

[60] F. Pages, A. Berger, M. Camus, F. Sanchez-Cabo, A. Costes, R. Molidor, B. Mlecnik, A. Kirilovsky, M. Nilsson, D. Damotte, T. Meatchi, P. Bruneval, P-H. Cugnenc, Z. Trajanoski, WH. Friedman and J. Galon, Effector memory T cells, early metastasis, and survival in colorectal cancer, $N$ Engl $\mathrm{J}$ Med 353 (2005), 2654-2666.

[61] H.S. Panda, J. Waxman and K. Sikora, Tumour markers, Brit J Hosp Med 51 (1994), 297-303.

[62] K.D. Pant and J.D. McCracken, Noninvasive colorectal cancer screening, Dig Dis Sci 47 (2002), 1236-1240.

[63] M.C. Plucinsky, J.J. Prorok and J.A. Alhadeff, Betahexosaminidase from colon and sera of dukes-classified colorectal cancer patients: activity levels, isoenzyme patterns, and kinetic properties, J Natl Cancer Inst 77 (1986), 57-62.

[64] J.W. Pollard, Tumour-educated macrophages promote tumour progression and metastasis, Nat Rev Cancer 4 (2004), 71-78.

[65] I.T. Said, A.M. Shamsuddin, M.A. Sherief, S.G. Taleb, W.F Aref and D. Kumar, Comparison of different techniques for detection of Gal-GAlNAc, an early marker of colonic neoplasia, Histol Histopathol 14 (1999), 351-357.

[66] O. Saitoh, W.C. Wang, R. Lotan and M. Fukuda, Differential glycosylation and cell surface expression of lysosomal membrane glycoproteins in sublines of a human colon cancer exhibiting distinct metastatic potentials, J Biol Chem 267 (1992), 5700-5711.

[67] K. Schulmann, M. Reiser and W. Schmiegel, Colonic cancer and polyps, Best Pract Res Clin Gastroenterol 16(1) (2002), 91-114.

[68] Senate Resolution 108, Designation of National Colorectal Cancer Awareness Month (http://www.cdc.gov.cancer/ colorctl/sres 108.htm.

[69] T. Shibata, A. Ochiai, Y. Kanai, S. Akimoto, M. Gotoh, N.
Yasui, R. Machinami and S. Hirohashi, Dominant negative inhibition of the association between $\beta$-catenin and c-erbB-2 by $\mathrm{N}$-terminally deleted $\beta$-catenin suppresses the invasion and metastasis of cancer cells, Oncogene 13 (1998), 883-889.

[70] W. Sulowicz, Activity of some lysosomal enzymes in neutrophils from peripheral blood of patients with digestive tract cancer at different clinical stages of the disease. A cytochemical study, Rev Esp Oncol 28 (1981), 509-514.

[71] S.D. Szajda, J. Snarska, M. Borzym-Kluczyk, B. Zalewska, N. Waszkiewicz, M. Bierć and K. Zwierz, Activity of $\beta$ galactosidase and $\alpha$-mannosidase in the serum of patients with colon adenocarcinoma, Contemporary Oncology 11 (2007), 64-66.

[72] S.D. Szajda, J. Snarska, Z. Puchalski and K. Zwierz, Lysosomal exoglycosidases in serum and urine of patients with colon adenocarcinoma. Hepatogastroenterology 84 (2008), 921-925.

[73] M. Takeichi, Cadherin cell adhesion receptors as a morphogenetic regulator, Science 251 (1991), 1451-1455.

[74] J. Weitz, M. Koch, J. Debus, T. Hohler, P.R. Galle and M.W. Buchler, Colorectal cancer, Lancet 365 (2005), 153-165.

[75] M.S. Wideł and M. Wideł, Mechanisms of metastasis and molecular markers of malignant tumor progression, I, Colorectal cancer, Post Hig Med Dosw 60 (2006), 453-470.

[76] S.J. Williams, M.A. McGuckin, D.C. Gotley, H.J. Eyre, G.R. Sutherland and T.M. Antalis, Two novel mucin genes downregulated in colorectal cancer identified by differential display, Cancer Res 59 (1999), 4083-4089.

[77] A. Velcich, J. Heyer, A. Fragale, C. Nicholas, S. Viani, R. Kucherpati, M. Lipkin, K. Yang and L. Augenlicht, Colorectal cancer in mice genetically deficient in the mucin MUC2, Science (2002), 1726-1729.

[78] A. Zalewska, K. Zwierz, K. Żókowski and A. Gindzieński, Structure and biosynthesis of human salivary mucins, Acta Biochim Pol 47 (2000), 1067-1079.

[79] M. Yuan, S.H. Itzkowitz, C.R. Boland, Y.D. Kim, J.T. Tomita, A. Palekar, J.L. Bennington, B.F. Trump and Y.S. Kim, Comparison of T-antigen expression in normal, premalignant, and malignant human colonic tissue using lectin and antibody immunohistochemistry, Cancer Res 46 (1986), 4841-4847. 


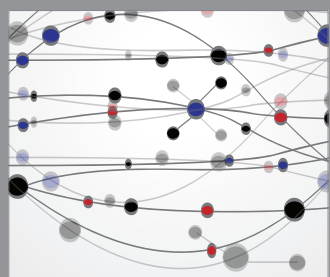

The Scientific World Journal
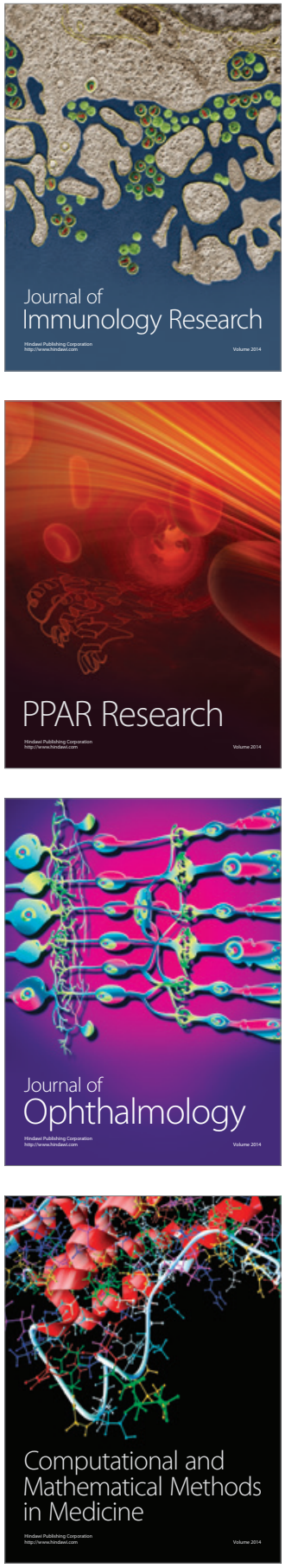

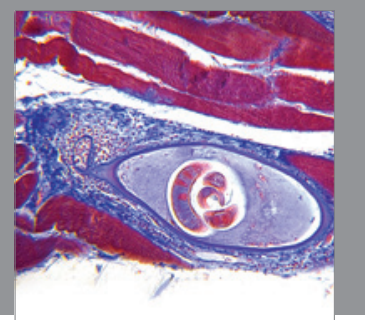

Gastroenterology

Research and Practice
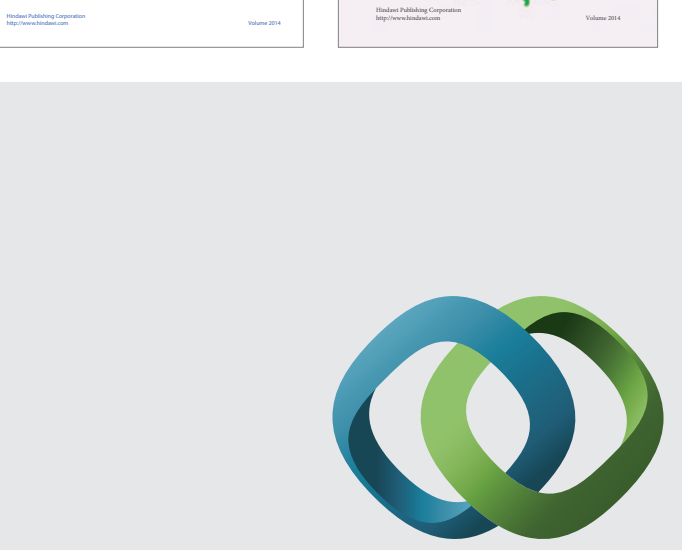

\section{Hindawi}

Submit your manuscripts at

http://www.hindawi.com
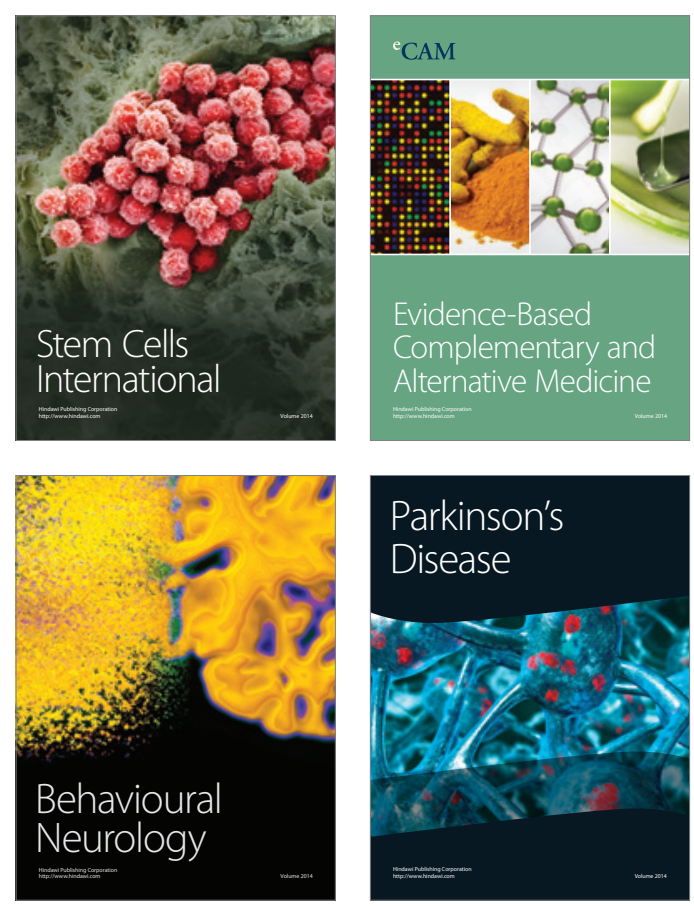

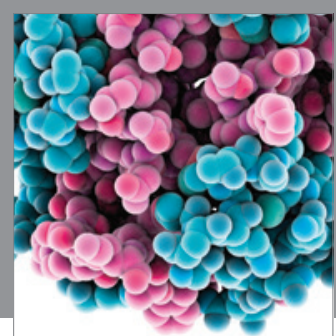

Journal of
Diabetes Research

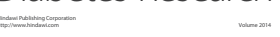

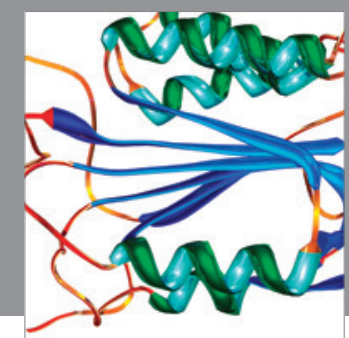

Disease Markers
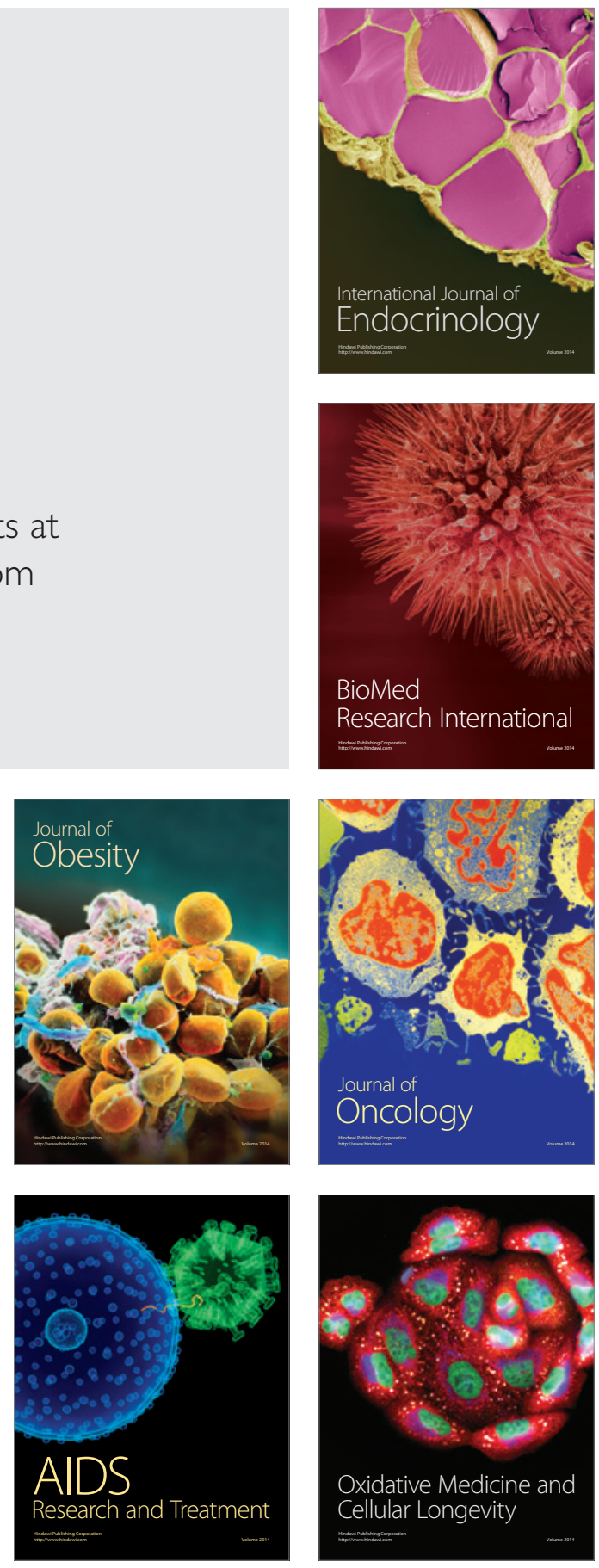